\title{
The kilometre who sailed thousands of miles
}

\section{Bartosz Panek}

Bartosz Panek is a journalist. His main interest is history, culture and travels. He works for the Polish Radio 2

When asked who he was, he used to reply: "I am a vagabond". Traveling became his passion and source of success.

In early 1920s, Wacław Korabiewicz arrived in Tczew, hoping he would be allowed to study at the newly established High Maritime School. Wacław had always dreamed of sailing but to make his great expectations real, he had to pass not only aptitude and knowledge tests, but also a physical examination. He entered into a doctor's room. The ophthalmologist looked very old and it was very uncertain if he can see well. The diagnosis did not belong to any kind of phrases that young men want to hear. Korabiewicz could not be a sailor because of poor sight. Be that as it may, he would be a seaman.

Wacław Korabiewicz represents the kind of people who, being brought up in lowlands and having no direct connection with the sea, long for some enormous space and can do much not to abandon their aspirations. I guess this explains why he eventually decided to become a physician, even though he claimed after many years that he had chosen medicine because of a peculiar atavism. His two grandfathers served during the tsarist period in the Imperial Russian Army as military surgeons. At the same time, Korabiewicz used also to say that medicine had appeared in is mind by accident, thanks to a conversation with one of his cousins. Wacław, very upset and despaired after having tried to work in a mine, heard from him: "If they do not want you, use the back door".

He was born in 1903 in Saint Petersburg. During the World War I, his family moved to Kharkov and Kiev and eventually to Lithuania where they settled in a manor near Kaunas, among rivers, lakes and deep woods. Just in his childhood, Wacław was making plans to sail. He often asked his aunts to embroider anchors, sails and boats on his clothes, being convinced that "there would be nothing else but sea" in his professional life. In 1915 he moved to Vilnius to attend a gymnasium and then to study. "You're a moody romantic, not a butcher" - said his teacher and these words turned prophetic. Young Korabiewicz thought he would immediately cure diseases. Surprisingly for him, the first 2 years of the curriculum were dedicated to practical exercises in a dissection room. That was very far from the youngster's wishes. So Wacław and his colleagues had to dissect a single vein or a lung from a dead body and then discuss the whole action. Numerous rows of the dead bodies reminded him of wax figures or exhibits. He wrote that museum artefacts were gaining academic seriousness. In the dissection room he spent 24 months, every day from 4 PM till midnight. Korabiewicz felt it would not be useful at all. He was annoyed and angry. These years were disappointing so he took quite crucial decision and enrolled in lectures at the faculty of literature and ethnography, not only to escape from a narrow perspective of the world that medicine was giving. He thought that the town, nowadays idealised by many people as the Florence of the North, was 'provincial, gossiping and religiously bigoted'. Korabiewicz hardly accepted it. Because there was some contrariness and jocularity in his character, he strove for breaching the monopoly of the academic corporations that were aiming at representing the whole student life.

"I imagined that students would be playful and, being single, eager to live life to the full. It turned out, however, that most of my peers felt good in a stiff atmosphere", he wrote. In Vilnius, there were 2 student corporations, Polonia and Batoria. They were competing in wrongly understood chivalry. Their members pretended to be extremely formal, they used some empty phrases as "May I possibly say something?" or "Would you mind if I introduce you Miss Kowalska?" Wacław must have felt like a stranger in that environment. With some help from his best friends, in 1923 he established a new organisation, called the Academic Club of Vilnius Vagabonds. Once a week they organised meetings and discussed issues concerning literature, psychology and traveling. The club also run a public collection of money in order to buy canoes in which its members would go sailing 
at the Narach Lake. “What a buzz! Can't find any word to describe that bliss" - he recalled in 1986.

In Vilnius, a town which belonged to Poland in the interwar period, Korabiewicz met several well know figures. He got to know Paweł Jasienica, a historian who after 1945 would be one of the best know Polish intellectuals, Stefan Jędrychowski, a politician, communist clerk and deputy prime minister in the 1950 as well as poets: Teodor Bujnicki, accused of collaboration with the Soviets, sentenced to death and assassinated in 1944 by the Polish resistance, and Czesław Miłosz, the would-be Nobel laureate in literature. And it was Miłosz who called him "the kilometre" because of his height (Wacław was almost 2 metre tall) and his walking habits. It happened that Korabiewicz disappeared for the whole day to wander around the town. He totally devoted himself to wandering and the club's activity, holding back his studies and even girls. He wrote that he would have swapped out a date for an exciting excursion. Wacław was quite famous, people recognised him, especially because of his bike excursions to Lithuania. He usually crossed the border in an illegal way, paying a short visit to his mother who was living near Kaunas.

In 1930 he was expected to graduate but he did not as he had failed one exam. Instead of the diploma, he organised an excursion. Club members were kayaking to Istanbul.

Next year Wacław finally passed all the exams and gained the diploma in general medicine which let him work at the city hospital in Vilnius. He did not like at all that practical side of medicine, too. Being a physician in a clinic, he was meeting many hypochondriacs who wanted to bilk a sick leave out of the doctor. On the contrary, during several night shifts at the maternity ward, he saw many would-be mothers who suffered from mishandling. He accused his older colleagues that they perceived women as machines which the only function is giving birth to the children. Other doctors scarcely shared his modern views. Wacław Korabiewicz was also truly appalled at the fact that he had to cure many women who had undergone an illegal abortion. They often arrived at the hospital because of a strong uterine bleeding or perforation. Undoubtedly, medicine did not become his passion. It is clear that it served him to embark on the board of the Gift of Pomerania.

The Gift of Pomerania (Dar Pomorza), formerly Prinzess Eitel Friedrich, is a vessel built in 1909 in Germany by Blohm and Voss. Poland bought it from France in 1929 for 7,000 GBP. A lion's part of the money was collected by the community of Pomerania. The Polish state, which had already regained independence and free access to the Baltic Sea, claimed it deserved such a craft. After renovation, which included fitting the vessel with an extra diesel engine, Dar Pomorza (called also White Frigate) became the sail training ship of the Polish Naval Academy in Gdynia. Many young men at that time aspired to serve in the navy of reborn motherland. Those who were not able or not allowed to do it shared, however, the same aspirations as Korabiewicz did. But only one person could take up a position as the on board physician.

In 1933 Korabiewicz paid a visit in the Ministry of Trade to get know who were holding that post. "Doctor Kamiński" - he was told. And immediately wrote a letter to him. "Honourable Doctor, I hope that you have been annoyed with constant traveling on board. If I am right, please accept my candidature and let me substitute for you". After a month Kamiński replied: "You probably are telepathic. Please come to Gdynia. The director of the school has just known everything".

Korabiewicz ordered a new uniform. However he was not an officer, he asked the tailor to sew the Rod of Aesculapius on both stripes of the suit. These ornaments resembled anchors and cause some misunderstanding between the doctor and the rest of the ship's staff. They think Korabiewicz wanted to impersonate a navigator. But they did not know he would be soon their personnel and the only doctor during the famous cruise around the world.

Korabiewicz joined the White Frigate's team when she was about to set off for her first journey around the globe via Panama Canal. However, after the first year of his duty, he felt annoyed with sailing and wanted to take leave. He told one of his friends that "regular meals and a comfortable bunk will not do". Longing for a real adventure, he thought the White Frigate was like a beautiful tram, nothing more. That is why Korabiewicz and his wife Janina Haazówna started up their travel to India. By canoe, of course. They rowed the Prut, the Danube, the Black Sea, crossed the Bosporus, then they were moving along the Turkish sea shore to reached Syria and the Euphrates which led them to Basra. Haazówna and Korabiewicz paced The Persian Gulf, arrived to Karachi and finally, via the Indus Delta, reached their final destination. Anyway, in the 1930s quite many Poles took up original travel initiatives. Leon Mroczkiewicz and Tadeusz Perkitny, having graduated from the university in Poznań, decided to go around the globe by train, ship or feet. On the other hand, journalists Halina and Stanisław Bujakowscy set out for a journey from Druskinnikai near Vilnius to Shanghai. While they travelled by motorcycle, Halina was writing a lovely diary, republished in 2011.

In 1935 Wacław returned on the board. The White Frigate was preparing for a next expedition around the globe. As Poland needed to raise its reputation, the ship headed to the Cape Horn and became the first Polish vessel that had ever circumnavigated this head. Reading Korabiewicz's books you can draw a conclusion that his being on duty was more a vacation than any type of service. He did not face up major challenges. One of the most demanding situations 
happened near the island of Tristan da Cunha, which lies on the ocean 2,800 km eastward from Cape Town.

Korabiewicz, having in mid-1930s no penicillin or sulphonamide, had to confront with an inflammation of the middle ear. The patient suffered from indescribable ache, fever and vomits. Wacław Korabiewicz ordered an injection, some pills of aspirin and compress, but next day that treatment turned out insufficient. The patient's tympanic membrane was swollen and there was high risk that without any surgical intervention he would have lost hearing. Despite the lack of essential equipment and a storm, Korabiewicz decided to operate. "What a responsibility! If I do it wrong, he will be deaf. But if I don't do it, he will die", he recalled. Using a small looking-glass instead of speculum, Wacław Korabiewicz perforated the membrane with a needle. He was lucky enough to make it accurately. After 2 weeks the White Frigate arrived at the Port of Cape Town, the patient was examined by a laryngologist who affirmed that the operation had been conducted professionally.

In August 1939 Dar Pomorza arrived to Sweden. At the outbreak of World War II, the White Frigate was arrested. Korabiewicz moved to London, then to Brazil where he organised aid to the Polish prisoners of war. $\mathrm{He}$ also participated in a scientific expedition to the Brazilian jungle about which he wrote a book. From 1943 to 1946 he represented the exiled Polish government in East Africa, taking care of the Polish refugees. After the war, he worked at the King George Memorial Museum in Dar es Salaam. And finally, he discovered his greatest passion: ethnography. Korabiewicz explored African peoples' folklore so effectively that he was expelled form Tanganyika. Local authorities found out that he had shipped many exhibits to Poland without any permission. He explained his attitude with Poland's history. Because of the partitions, Poland, as an independent state, could not participate in $19^{\text {th }}$ century discoveries.
In 1976, during a radio broadcast, he explained that he had always wanted to overcompensate it.

Thus, the exhibits he collected belong nowadays to various museums in Toruń, Gdańsk as well as New York, London and Dar es Salaam. But the lion's part of those African artefacts (1,682 pieces: jewellery, masks, sculptures, combs and even a sailboat from East Africa) he donated to the National Museum of Ethnography in Warsaw.

Between 1954 and 1956 he worked in Ethiopia as a physician. His opinions about the country and its society seem today quite colonial. Although Korabiewicz witnessed Africa's decolonisation, the reader will find no paragraph about that phenomenon in his book. He behaved as if he had been mentally rooted in the 1930s. In a book, titled "Asclepius in Ethiopia", Korabiewicz claims that the level of health care in the Haile Selassie's state was highly lamentable. People suffered from tapeworm infestations and advanced stages of syphilis. But at the same time he describes his impatience because of the fact that "one in three patients couldn't get out of the doctor's room as they didn't know what a door handle was".

He returned to Poland in 1958 but did not give up traveling. "I don't like preparations, I like the real adventure. I like not to know where I will sleep and what I will eat. I love unpredictability because I'm a tearaway, not an accountant", he confessed in a radio broadcast in 1974 . One of his biggest expeditions took place in the mid-1960s to Timbuktu. He wrote almost 30 books.

"Tumbleweed through a bay which has been silver-plated by the moon, you can get a glimpse of the next headland. It immediately becomes your destination. No point in looking away. This rock monster, snoozing at the water, has already captivated you".

Perhaps this paragraph, written during canoe expedition to India in 1930s, explains his last will. Korabiewicz wished to be burned and wanted his ashes to be sunk in the Baltic Sea. Undoubtedly, his life turned the full circle. 